\title{
RANCANG BANGUN SISTEM INFORMASI MANAJEMEN RANTAI PASOKAN DI PT ARGO PANTES
}

\author{
Andita $^{1}$, Tri Ika Jaya ${ }^{2}$ \\ ${ }^{1,2}$ Prodi Sistem Informasi, Fakultas Teknologi Informasi, Universitas Budi Luhur Jakarta \\ 2tri.ikajaya@budiluhur.ac.id
}

\begin{abstract}
ABSTRAK
Supply chain management (SCM) merupakan proses manajemen rantai pasok mulai dari proses pengadaan bahan baku, produksi hingga hasil jadi sampai ke tangan konsumen. Tujuan diterapkannya SCM pada perusahaan-perusahaan besar salah satunya adalah untuk membangun hubungan baik dengan para Supplier. Salah satu cara dengan penerapan SCM. Dengan menerapkan ini diharapkan proses pengadaan bahan baku menjadi lebih mudah dan dapat menciptakan hubungan baik antar sesama perusahaan. Selain itu dari sisi internal perusahaan itu sendiri, seperti produksi juga harus diperhatikan. Proses pengiriman dan pelayanan kepada konsumen merupakan hal yang perlu diperhatikan agar keduanya sama-sama merasa nyaman. PT.Argo Pantes Tbk mengembangkan sistem informasi manajemen rantai pasokan dengan beberapa tahap antara lain: menganalisa proses bisnis berjalan disana, menganalisa masalah yang ada pada proses pengadaan serta memikirkan dampak dan kendala apa yang akan terjadi jika diterapkannya SCM. Solusi utama yang ditawarkan oleh sistem tersebut adalah adanya antarmuka pengguna yang melibatkan pihak supplier untuk melakukan penawaran harga secara langsung melalui sistem. Notifikasi, negosiasi dan approval dilakukan secara online, diharapkan dapat memotong waktu pemesanan bahan baku menjadi lebih singkat. Pengujian pada penelitian ini baru pada fungsional sistem menggunakan metode black box testing.
\end{abstract}

Kata kunci : Supply chain management (SCM), Purchase Requisition, Purchase Order

\begin{abstract}
Supply chain management (SCM) is a supply chain management process starting from raw material procurement, production to finished product reaches the consumer. Objective implementation of SCM in large companies one of which is to establish a good relationship with the Supplier. One way to implementation of SCM. By applying the expected raw material procurement process becomes easier and can create good relationships between the members of the company. In addition, from the internal side of the company itself, such production should also be considered. The process of delivery and service to consumers is to note that both are equally as comfortable. PT.Argo Pantes Tbk develop supply chain management information system with multiple stages include: analyzing the business processes running there, analyzing the existing problems in the procurement process as well as considering the impact and constraints of what will happen if the implementation of SCM. The main solutions offered by these systems is their user interfaces that involve suppliers to bid directly through the price system. Notifications, negotiation and approval is done online, is expected to cut the time of ordering raw materials becomes shorter. Tests on new research on the functional system using black box testing methods.
\end{abstract}

Keywords : Supply chain management (SCM), Purchase Requisition, Purchase Order 


\section{PENDAHULUAN}

Dalam suatu perusahaan proses pengadaan bahan baku dari Supplier merupakan ujung tombak keberhasilan perusahaan tersebut, untuk itu diperlukan adanya suatu cara untuk mempermudah proses tersebut. Supply Chain Management (SCM). SCM merupakan jaringan perusahaan-perusahaan yang secara bersamasama bekerja untuk menciptakan dan menghantarkan suatu produk ke tangan pemakai akhir. SCM merupakan integrasi beberapa kunci proses bisnis dari end user hingga para pemasok yang menyediakan produk, jasa, dan informasi yang menjadi nilai tambah untuk para pelanggan dan stakeholder,atau bisa dikatakan suatu alat atau pendekatan pengelolaannya. Salah satu faktor yang berpengaruh cukup besar dalam keberhasilan penerapan SCM adalah Internet. Dengan adanya Internet pihak-pihak yang ada dalam jaringan SCM dapat membagi informasi dengan mudah dan cepat.

PT. Argo Pantes merupakan pabrik industri penghasil produk garmen (kain) terbesar di Indonesia. Bagian pengadaan bahan baku dari Supplier ke Gudang dituntut memberikan informasi yang cepat dan akurat. Hal ini disebabkan bahwa produk jadi sangat tergantung pada persediaan bahan baku. Perusahaan diharuskan menjalin hubungan dengan Supplier untuk menjamin pengadaan bahan baku berjalan lancar. Bagian Purchasing, PPC (Planning Product Control), Accounting, Gudang dan Supplier merupakan bagian-bagian penting yang terlibat dalam proses pembelian dan pengadaan bahan baku.

Beberapa masalah pengadaan yang sering terjadi saat ini adalah keterlambatan pengadaan barang baku. Proses pengadaan yang lambat disebabkan antara lain:(1) Lambatnya Supplier merespon penawaran harga via email; (2) dari segi prosedur yang berbelit dan panjang karena perputaran dokumen masih berjalan dari tangan ke tangan. Contoh proses persetujuan dokumen seperti purchase requisition yang berjalan lama karena pegawai yang bersangkutan sedang keluar kota atau cuti, sehingga menunggu tanda tangan dibubuhkan saat pegawai ada di tempat.

Berdasarkan permasalahan tersebut, maka penelitian ini bertujuan: (1) Mengidentifikasi proses bisnis serta menganalisa permasalahan yang berkaitan dengan pemenuhan pemesanan bahan baku pada PT Argo Pantes; (2) Memberikan solusi sebagai pemecahan masalah yang berguna untuk meningkatkan proses bisnis perusahaan.

\section{LANDASAN TEORI}

\section{a. Manajemen Rantai Pasok/Supply \\ Chain Management}

Menurut Indrajit dan Djokopranoto [1] supply chain adalah:"suatu tempat organisasi menyalurkan barang produksi dan jasanya kepada para pelanggannya". Lee dan Whang [2] mendefinisikan supply chain management adalah: "Suatu sistem jaringan yang terdiri atas beberapa perusahaan yang memiliki tujuan sama sebagai tempat organisasi menjalankan barang dan jasa kepada pelanggan".

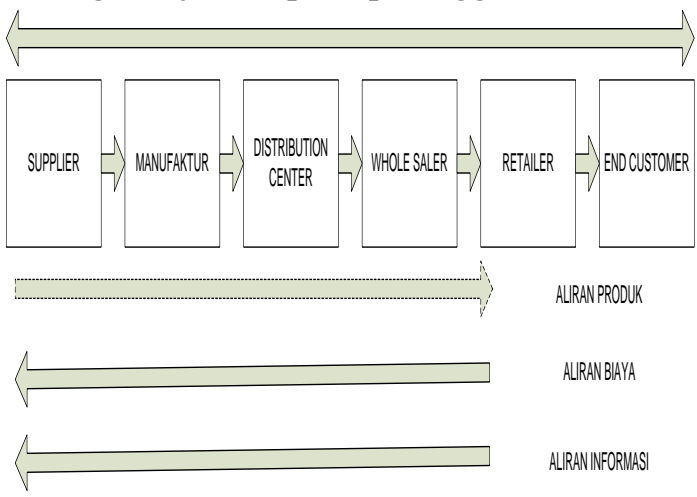

Gambar 1. Struktur Rantai Pasokan/SCM

\section{b. Komponen Dari Supply Chain Management}

Komponen Supply Chain Management menurut Turban [3] terdiri dari tiga komponen utama yaitu : (1) Rantai Suplai Hulu/Upstream Supply Chain Segment, meliputi aktivitas perusahaan manu-facturing dengan para supplier dan koneksinya (para penyalur secondtier). (2) Manajemen Internal Suplai Rantai/Internal Supply Chain Segment, meliputi semua proses inhouse yang digunakan dalam mentransformasikan input dari supplier ke dalam keluaran organisasi itu.; (3) Segmen Rantai Suplai Hilir/Downstream Supply Chain Segment meliputi aktivitas yang melibatkan pengiriman produk kepada pelanggan akhir.

\section{c. Cakupan Supply Chain Management}

Menurut Pujawan [3] bila kita mengacu pada sebuah perusahaan manufaktur, kegiatan- 
kegiatan utama yang masuk dalam klasifikasi SCM adalah (1) Pengembangan Produk, mencakup kegiatan riset pasar, merancang produk baru dengan melibatkan supplier dalam perancangan produk baru.; (2) Pengadaan barang, terdiri dari kegiatan memilih supplier, mengevaluasi kinerja supplier, pembelian bahan baku dan komponen lain, memonitor supply risk, membina dan memelihara hubungan dengan supplier; (3) Perencanaan dan Pengendalian, meliputi Demand Planning, peramalan permintaan, perencanaan kapasitas, perencanaan produksi dan persediaan; (4) Produksi, terdiri dari Eksekusi produksi, pengendalian kualitas.; (5) Distribusi, mencakup kegiatan Perencanaan jaringan distribusi, panjadwalan pengiriman, mencari dan memelihara hubungan dengan perusahaan jasa pengiriman, memonitor service level di tiap pusat distribusi [5].

\section{d. Keuntungan Penerapan Supply Chain} Indrajit dan Djokopranoto [1] menyebutkan bahwa keuntungan menerapkan supply chain ialah: (1) Mengurangi persediaan barang (over stock); (2) Menjamin kelancaran arus barang; (3) Menjamin mutu.

\section{e. Proses Supply Chain Management}

Menurut Indrajit dan Djokopranoto [1] dalam Supply Chain ada beberapa pemain utama (perusahaan) yaitu Suppliers, Manufacturers, Distribution, Retail Outlet, Customer. Adapun proses mata rantai yang terjadi antar pemain utama itu antara lain sebagai berikut [4] : (a) Suppliers, Jaringan bermula dari sini, yang merupakan sumber yang menyediakan bahan pertama, di mana mata rantai penyaluran barang akan mulai. Sumber pertama ini dinamakan Suppliers; (b) Suppliers - Manufacturers, rantai pertama dihubungkan dengan rantai kedua, yaitu manufacturer. Misalnya, inventoris bahan baku, bahan setengah jadi, dan bahan jadi yang berada di pihak suppliers, manufacturers, dan tempat transit. (c) Suppliers - Manufacturers Distribution, Barang yang sudah dihasilkan oleh Manufacturers akan segera disalurkan ke pelanggan melalui distributor dan selanjutnya jatuh ke tangan yang lebih kecil yaitu retailers atau pengecer. (d)Suppliers - Manufacturers Distribution - Retail Outlets, (e) Suppliers Manufacturers - Distribution-Retail Outlets Customers

\section{HASIL DAN PEMBAHASAN}

\subsection{Analisa Sistem Berjalan}

Proses bisnis yang sedang berjalan saat ini dikelompokkan menjadi 2 proses besar yaitu (1) pemesanan barang ke supplier dan (2) penerimaan barang oleh supplier. Proses pemesanan barang melibatkan 3 bagian yaitu (a) marketing: mengajukan rencana tenun, (b) PPC (production, planning, control): menyediakan informasi stok benang yang harus dipesan, (c) Purchasing:mengajukan pesanan benang dan (d) accounting: menyetujui dan mencatat pesanan benang (Purchase Order).

Penerimaan barang dari supplier terjadi di gudang. Bagian gudang melakukan verifikasi barang yang datang harus sesuai dengan PO, Surat Jalan dan Packing List. Dokumen yang dikeluarkan oleh bagian gudang adalah Bukti Penerimaan Barang (BPB) yang harus ditandatangani oleh: a) Kepala Bagian Benang, b) Manager Benang, c) Kepala Departemen Bahan Penunjang, dan d) Pimpinan Perusahaan.

Permasalahan yang terjadi pada lambatnya proses pemesanan benang disebabkan oleh 3 hal berikut: (1) dari sisi Supplier, respon dari Supplier dalam proses pemesanan via email terasa lambat padahal proses penawaran harga terjadi disana, (2) pegawai yang harus memberi tanda tangan persetujuan pemesanan, sering tidak ada ditempat seperti keluar kota dan sebagainya, (3) prosedur pemesanan terlalu panjang dan berbelit karena perpindahan dokumen dari tangan ke tangan. Berdasarkan kondisi tersebut diatas, perlu dibuat sistem informasi manajemen rantai pasokan yang terintegrasi dari bagian hulu ke hilir. 


\subsection{Rancangan Sistem Usulan}

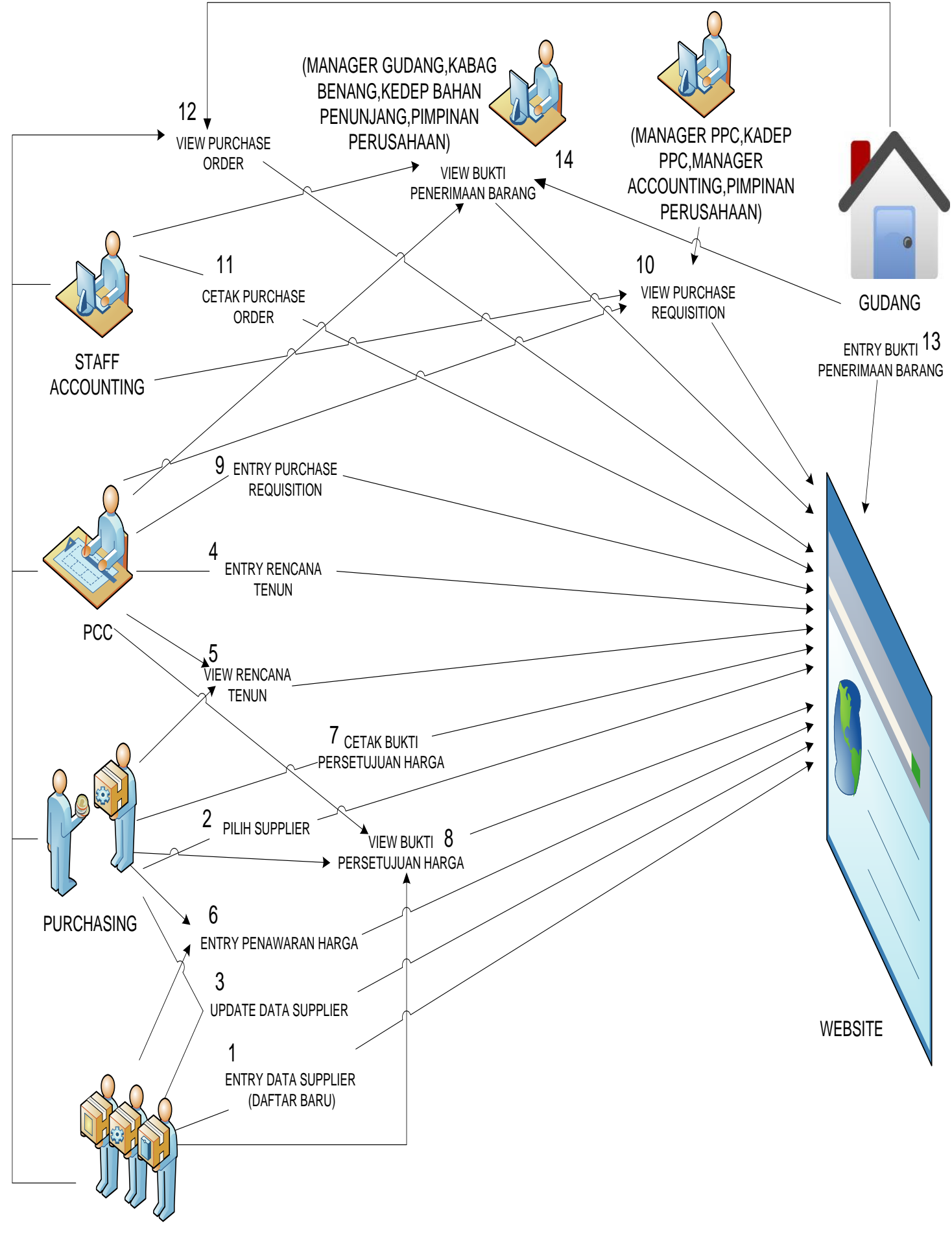

SUPPLIER

Gambar 2 Rich Picture Usulan Sistem Informasi Manajemen Rantai Pasokan

Gambar 2 menunjukkan bahwa salah satu usulan solusi terhadap masalah lambatnya pemesanan barang adalah membangun sebuah portal yang digunakan untuk melakukan pemesanan barang. Supplier diberi hak akses dan diperbolehkan melakukan penawaran harga secara berkala. Dengan demikian ketika bagian purchasing akan membuat purchase requisition sudah tersedia data harga bahan baku yang dibutuhkan. Aproval dilakukan secara online dan pembubuhan tanda tangan dapat dilakukan ketika pegawai ada di tempat. 
Perancangan sistem informasi ini terdiri dari beberapa tahap. Tahap pertama ialah membuat (a) model sistem, (b) model data, (c) model navigasi sistem, (d) model antarmuka pengguna. Model sistem digambarkan dalam bentuk diagram antara lain package, use case, dan activity diagram. Dibawah ini ditunjukkan diagram tersebut.
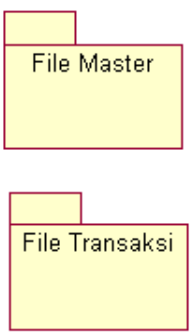
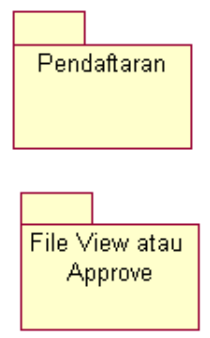
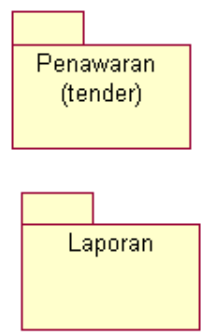

Gambar 3. Package Diagram

Pada gambar 3 diatas, sistem dibagi menjadi 6 paket yang terdiri dari 1) paket file master, 2) file transaksi, 3) pendaftaran, 4) penawaran, 5) file View atau approve dan 6) laporan. Paket file master digunakan untuk mengelola data master sedangkan data transaksi dikelola di dalam paket file transaksi. Paket penawaran digunakan untuk mengelola proses bisnis penawaran harga oleh supplier. Paket pendaftaran digunakan untuk melakukan pendaftaran pengguna sistem. Paket file view atau approve digunakan untuk proses (approval). Paket laporan digunakan untuk mengelola output sistem berupa laporan.

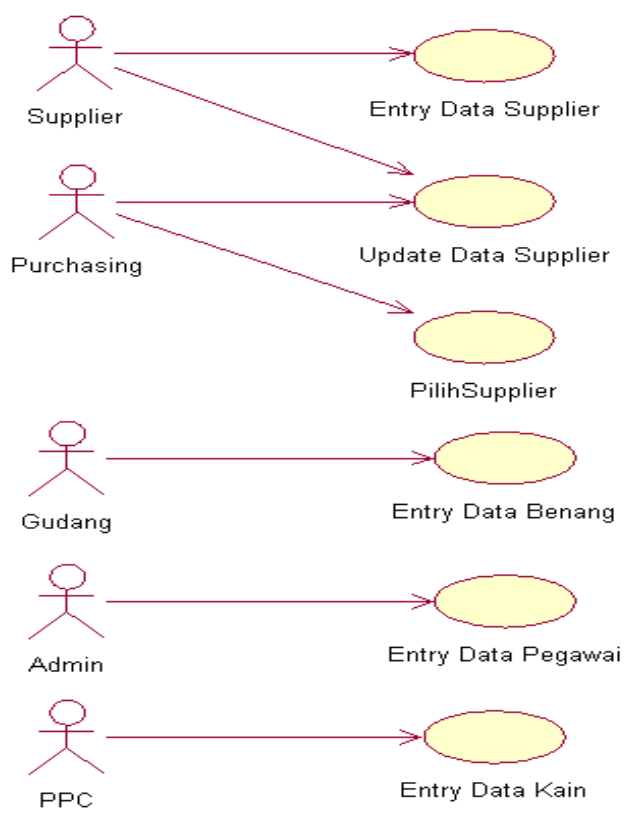

Gambar 4. Use Case Diagram Entry Data
Gambar 4 menunjukkan use case diagram pengelolaan master data. Diagram tersebut merupakan salah satu use case dari keseluruhan use case dalam package diagram. Berdasarkan use case itu dibuatlah narasinya dilanjutkan activity diagram.

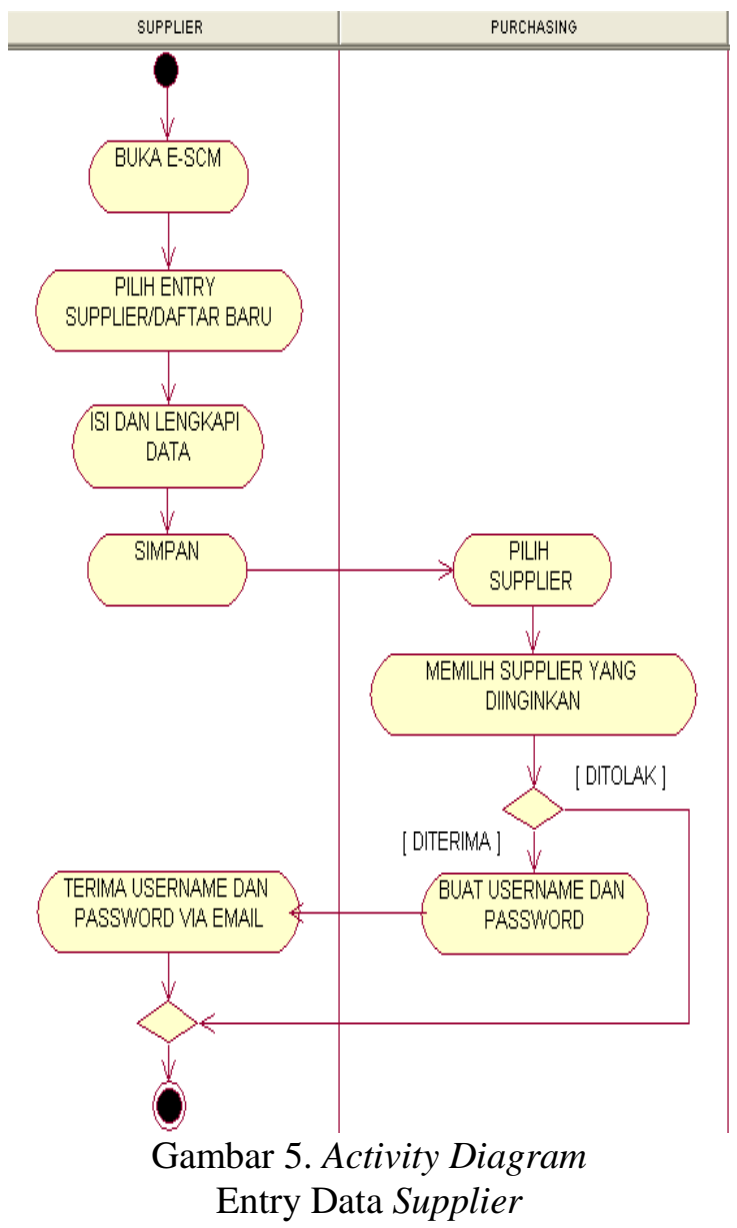

Setelah model sistem langkah berikutnya adalah membuat model data berupa diagram relasional entitas dan membuat struktur data. Antarmuka pengguna dibuat menggunakan perangkat lunak MS visio, sehingga hasilnya mendekati aplikasi riilnya.

\subsection{Pembahasan Hasil}

Proses bisnis di PT Argo Pantes Tbk yang saat ini berjalan, belum efisien dan cenderung berbelit dalam hal prosedur. Hal itu terlihat pada proses bisnis berjalan yaitu pembelian bahan baku benang, bagian Purchasing masih menggunakan media email atau telepon untuk tawar menawar harga dengan Supplier. Pada sistem ini dibuatkan form penawaran harga untuk bagian Purchasing dan Supplier dalam melakukan transaksi penawaran dan pembelian benang. 


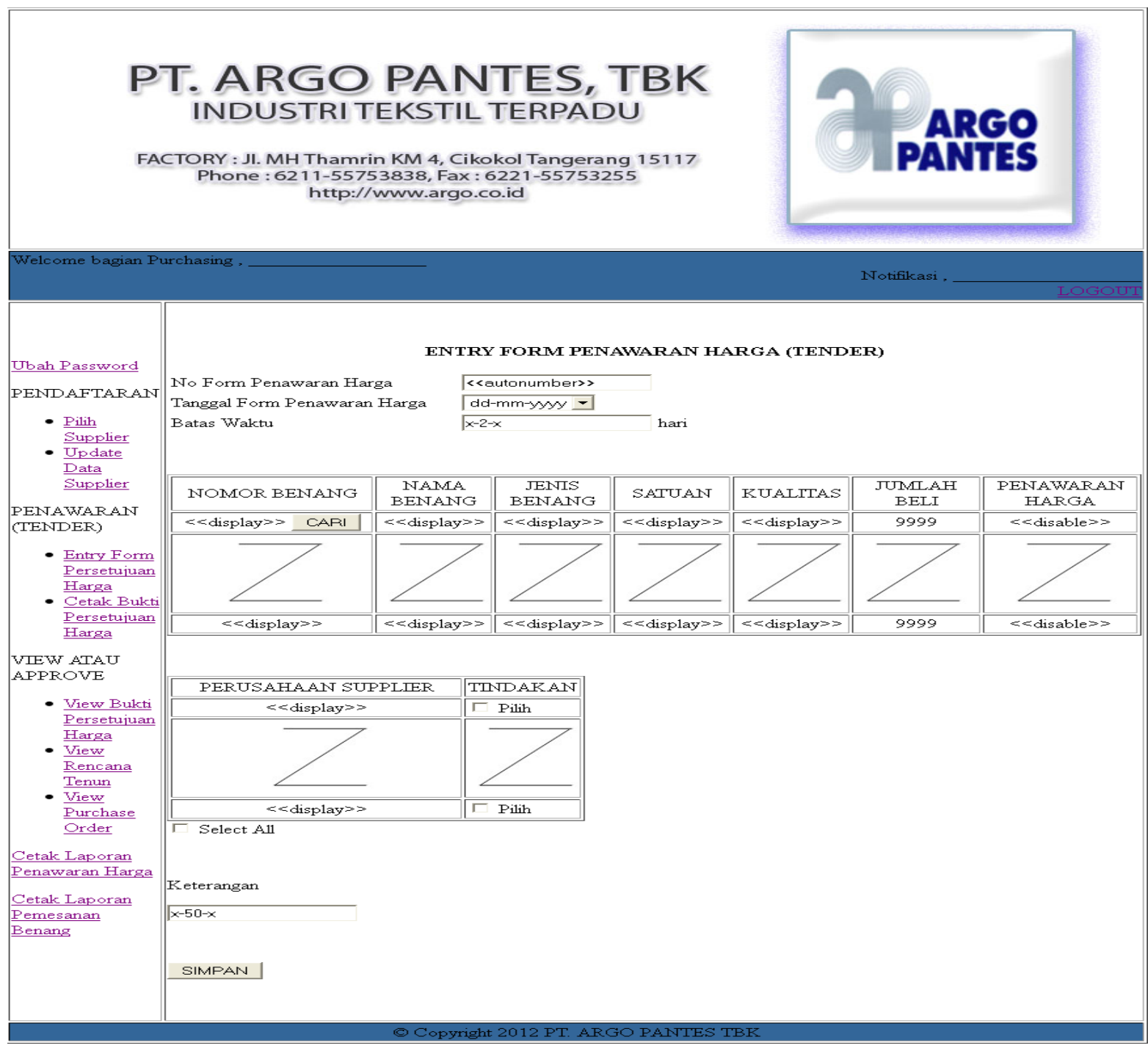

Gambar 6. Form Penawaran Harga (Tender) Sisi Purchasing

Form diatas adalah tampilan penawaran harga yang dilihat oleh bagian Purchasing. Form ini berfungsi untuk melakukan transaksi permintaan benang dari bagian purchasing kepada Supplier. Memiliki aturan seperti tender, dimana nantinya Supplier diberi batasan waktu untuk melakukan penawaran harga. Jika waktu telah habis, Supplier tidak dapat lagi melakukan penawaran. Penawaran harga yang di lakukan oleh Supplier merupakan harga tetap dan tidak dapat diubah jika telah disepakati antara Purchasing dan Supplier.

Form terdiri dari 4 bagian, yang pertama adalah identitas form, yang terdiri dari nomor form penawaran harga yang autonumber, tanggal form penawaran harga dan batas waktu tender. Dibawah identitas form adalah jenis benang yang akan dipesan ke supplier. Bagian purchasing tidak dapat mengisi (disable) kolom penawaran harga, karena harga akan diisi oleh supplier. Bagian Purchasing dapat memilih ke beberapa atau ke semua (select all) Supplier untuk melakukan penawaran benang yang ingin dibeli, dengan meng-klik pada daftar checklist pada kolom Tindakan. Jika form sudah lengkap, dapat diakhiri dengan meng-klik tombol Simpan, dan sistem secara otomatis akan mengirimkan pemberitahuan atau pengingat berupa notifikasi dan email ke Supplier.

Demikian salah satu contoh form yang digunakan untuk mengatasi permasalahan lambatnya waktu pemesanan benang yang dihadapi oleh perusahaan. Dengan adanya notifikasi otomatis dan berkala, diharapkan supplier yang sudah jadi rekanan perusahaan dapat dengan mudah berkomunikasi dan bertransaksi secara cepat dan akurat. Pengujian sistem dilakukan secara black box testing, yaitu menggunakan pengujian fungsi-fungsi dari sistem yang dikembangkan. 


\section{KESIMPULAN DAN SARAN}

\subsection{Kesimpulan}

Berdasarkan penelitian dan perancangan yang telah dilakukan pada PT Argo Pantes Tbk, maka dapat disimpulkan bahwa Sistem Informasi Manajemen Rantai Pasokan yang dikembangkan di PT Argo Pantes Tbk dapat menjadi solusi untuk meningkatkan efektifitas dan efisiensi peda pemesanan barang baku (benang). Beberapa fitur yang mendukung solusi tersebut antara lain:

a. Memberi kesempatan kepada supplier untuk terlibat secara langsung ke dalam sistem pada proses penawaran harga secara online.

b. Proses persetujuan (approval) seperti pada dokumen purchase requisition dapat dilakukan secara online, sehingga dengan internet dapat melakukan approve dimana saja mereka berada.

c. Kurangnya komunikasi antar pegawai di antar bagian menyebabakan keterlambatan proses pemenuhan. Untuk itu dengan adanya notifikasi/pengingat di sistem diharapkan dapat meminimalisir kesalahan manusia.

\subsection{Saran}

Berdasarkan penelitian yang telah dilakukan, maka dapat dilakukan saran-saran sebagai berikut :

a. Untuk kelancaran penerapan sistem e-SCM di PT Argo Pantes Tbk perlu mengadakan training untuk para pegawai tentang bagaimana cara menggunakan sistem baru tersebut.

b. Perlu dilakukan penelitian untuk mengukur tingkat efektifitas dan efisiensi penggunaan sistem tersebut, baik dari sisi usability, kepuasan pengguna maupun kinerja sistem.

\section{DAFTAR PUSTAKA}

[1] Indrajit dan Richardus Djokopranoto. Konsep Supply Chain Management: strategi mengelola manajemen rantai pasokan bagi perusahaan modern di indonesia. Jakarta: Grasindo, 2006

[2] Turban, Efraim, David King, Jae Lee, dan Dennis Viehland, Electronic Commerce: Managerian Perspective. New Jersey: Prentince Hall, 2004.

[3] . Liana Anatan, S.E., M.Si., Lena Ellitan, S.E., M.Si. Ph.d. SCM Teori Dan Aplikasi. Jakarta: Alfabeta, cv 2008.

[4] Pujawan, I Nyoman, Supply Chain Management. Surabaya: Penerbit Guna Widya, 2005.

[5] Nugrahanti, Fatim, dkk., Analisa Perancangan Sistem Informasi Managemen Rantai Pasok (Supply Chain) Pada Perusahaan Pembuat Peralatan Tambang (Studi Kasus Pt. Refindo Inti Selaras Indonesia), Prosiding: Seminar Nasional Teknologi Informasi dan Komunikasi (SENTIKA), Yogyakarta, 2014

[5] Nugrahanti, Fatim, dkk., Analisa Perancangan Sistem Informasi Managemen Rantai Pasok (Supply Chain) Pada Perusahaan Pembuat Peralatan Tambang (Studi Kasus Pt. Refindo Inti Selaras Indonesia), Prosiding: Seminar Nasional Teknologi Informasi dan Komunikasi (SENTIKA), Yogyakarta, 2014 
